\title{
ACID MINE DRAINAGES FROM COPPER MINES IN THE SOUTHEAST SERBIA - LOCAL PROBLEM WITH AN INTERNATIONAL IMPACT
}

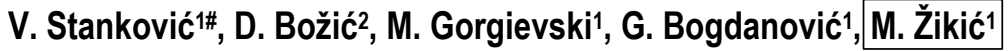 \\ 1 University in Belgrade, Technical Faculty, Bor, Serbia \\ ${ }^{2}$ Mining and Metallurgy Institute Bor, Bor, Serbia
}

Received: January 29, 2021; Accepted: April 20, 2021

\begin{abstract}
Through this study special attention was paid to AMDs, originating from copper mines, containing different heavy metal ions, and a certain amount of sulphuric acid. The research was conducted on the territory encompassing the RTB Bor mines (now Serbia Zijin Bor Copper). The AMDs occurrences, their water composition, metal potential, and impact on the local surface waters were determined. The major amount of mine waters flow into the Krivelj River damaging extremely its water quality. The research also included monitoring the Timok river water quality along its course from the Krivelj River inflow to the confluence with the Danube. Evaluating the metal losses, it was found that every year around 360 tons of copper, $>500$ tons of iron, and 30 tons of zinc from mine waters are lost, as being transported via the Krivelj River to the Timok and then to the Danube.
\end{abstract}

Key words: Heavy metal ions; Mining wastes; Mine water; AMD; Water pollution.

\section{Introduction}

Maintenance of mining wastes, produced in heavy metal mines, includes: dumps of out-of-balance ores, abandoned mining works, not excavated ore body edges, flotation tailings, mean significant costs for the company, as well as a serious concern for society, due to environmental problems closely related to the company's mining activities. At the same time, these wastes are valuable resources that could be exploited and reprocessed, in order to produce an additional amount of metals, reducing in such a way a risk, which would cause long-lasting damage to communities located in mines neighborhood. Mine works are, as a rule, associated with the generation of mine waters, which particularly represent a huge threat to the living world in the environment of their origin. Active, or closed, under closure, or even abandoned, whether it is a metal or nonmetallic mine, they produce bigger or fewer volumes of mine waters, contaminated with dissolved minerals residues. These waters must be purified, in order to protect the environment, which causes a need for investing a large amount of money for this purpose. Therefore, mine waters remain a major concern, for which neither the European
Community nor the rest of the world has found a proper solution yet [1].

Here, special attention will be paid to mine waters, originating from copper metal mines, known as acid mine drainages (AMDs), which contain, besides copper and other heavy metal ions, a certain amount of sulphuric acid making them acidic. Although, AMDs cause global environmental pollution problem, which is difficult to be estimated, some studies suggest that up to ca. 19,300 km of rivers, and around 72,000 ha of lakes and similar water reservoirs around the world had been polluted with considerably high concentrations of various metal-sulfate salts and sulphuric acid [2]. The situation in the Balkan countries is even worse in a view of producing and discharging AMDs into smaller and bigger rivers, polluting them heavily and irretrievably as a consequence of ores mining in more than 20 active copper mines [2-5].

The aim of this study was to recognize and locate the place of each AMD within the RTB copper mines; to define and determine the copper potential of each source and to estimate the metal amounts which are lost in this way. Also, to highlight the full impact of these mine waters on the environment. 


\section{AMDs generation}

\subsection{General about AMDs}

Long-term metallic ores excavation and processing in the Balkan Countries has devastated large areas of land and surface water streams around the mine sites $[3,5]$. The mining technology is such that it produces huge amounts of mining wastes deposited at the mine edges, which can be considered as a permanent environmental threat. The AMDs, originating either from such dumps or from active or abandoned copper mines, contain a considerable amount of heavy metal ions, mostly copper and ferrous/ferric ions, as well as sulphuric acid. The ions are generated as a consequence of bio-, electro-, and chemical reactions that occur between oxygen, water, native autotrophic microorganisms, and sulfide minerals - pyrite and marcasite $\left(\mathrm{FeS}_{2}\right)$, before all, forming major AMD ionic constituents $[6-8,20]$. The process stoichiometry can be described through the three main steps:

a) Oxidation of iron sulphide followed by the oxidation of other sulphide minerals by ferric- ions:

$2 \mathrm{FeS}_{2}+7 \mathrm{O}_{2}+2 \mathrm{H}_{2} \mathrm{O} \rightarrow 2 \mathrm{Fe}^{2+}+4 \mathrm{SO}^{2-}{ }_{4}+4 \mathrm{H}^{+}$ chemical step

$2 \mathrm{FeS}_{2}+7.5 \mathrm{O}_{2}+\mathrm{H}_{2} \mathrm{O} \rightarrow \mathrm{Fe}_{2}\left(\mathrm{SO}_{4}\right)_{3}+\mathrm{H}_{2} \mathrm{SO}_{4}$ bacterial step

$\mathrm{FeS}_{2}+14 \mathrm{Fe}^{3+}+8 \mathrm{H}_{2} \mathrm{O} \rightarrow 15 \mathrm{Fe}^{2+}+2 \mathrm{SO}^{2-}{ }_{4}+16 \mathrm{H}^{+}$

b) Oxidation of ferrous- to ferric- ion:

$4 \mathrm{Fe}^{2+}+\mathrm{O}_{2}+4 \mathrm{H}+\rightarrow 4 \mathrm{Fe}^{3+}+2 \mathrm{H}_{2} \mathrm{O}$

c) Hydrolysis and precipitation of ferric- and other heavy metal ions at an elevated $\mathrm{pH}$ :

$\mathrm{Fe}^{3+}+3 \mathrm{H}_{2} \mathrm{O} \rightarrow \mathrm{Fe}(\mathrm{OH})_{3}+3 \mathrm{H}^{+} \quad \mathrm{pH} \geq 3$

Once the sulphuric acid is produced, the other heavy metal oxides, carbonates, or hydro-carbonates will react with it forming corresponding sulfates. The ultimate result is a runoff of mine waters characterized by an elevated acidity and high concentration of various metal ions. In fact, mine water chemical composition is similar to the ore body mineral structure that is (or was) under exploration. The process itself is very slow and is being dramatically accelerated by mining activities, mainly because of the sulfide minerals exposure to air and moisture. By completing the mining activities, AMD origination will be continued for a long time, even more intensively in closed, or abandoned mines, than in the active ones [9]. From such mining sites AMDs form seepages and ponds at the subjacent of dumps, from which mine waters frequently flow into surrounding rivers in an uncontrollable way [10-12]. Besides copper and ferric/ferrous ions, as major metal constituents, the other transition metal ions are inevitably present in AMDs, with considerably lower concentrations than copper, but above the maximum allowed concentration (MAC), defined by local regulations. Most of these ions are toxic, even more than $\mathrm{Cu}^{2+}$, as $\mathrm{Pb}^{2+}, \mathrm{Cd}^{2+}, \mathrm{Be}^{2+}$, $\mathrm{Hg}^{2+}, \mathrm{Bi}^{2+}, \mathrm{Te}^{2+} / \mathrm{Te}^{4+}, \mathrm{As}^{3+} / \mathrm{As}^{5+}, \mathrm{Cr}^{6+}, \ldots$; some of them could be considered as valuable, or both - toxic and valuable, as $\mathrm{Zn}^{2+}, \mathrm{Ni}^{2+}, \mathrm{Co}^{2+}, \mathrm{Mn}^{2+}$, when they appear together with copper ions in a higher concentration, as is the case with mining waters from polymetallic ore bodies. The typical composition of mine waters from three different sites on the globe, in order to illustrate the previous statements is presented in Table 1.

Table 1 Linguistic scales for the weight of criteria

\begin{tabular}{|c|c|c|c|c|}
\hline \multirow[b]{2}{*}{$\begin{array}{c}\text { Origin of } \\
\text { mine } \\
\text { water }\end{array}$} & \multicolumn{4}{|c|}{ Concentration of metal ions, $\mathrm{mg} \mathrm{dm}^{-3}$} \\
\hline & $\begin{array}{c}\text { Dabaos } \\
\text { Han, } \\
\text { Guangdong, } \\
\text { China [13] }\end{array}$ & $\begin{array}{c}\text { Santa } \\
\text { Rosa, } \\
\text { Spain [12] }\end{array}$ & $\begin{array}{c}\text { Cerovo } \\
\text { Mine, Bor, } \\
\text { Serbia [4] }\end{array}$ & $\begin{array}{l}\text { MAC }^{*}, \\
{[22,23]}\end{array}$ \\
\hline $\mathrm{Fe}^{2} / \mathrm{Fe}^{3+}$ & 331.17 & $694-845$ & 0.14 & 1 \\
\hline $\mathrm{Cu}^{2+}$ & 14.80 & $15-46$ & $130-150$ & 0.1 \\
\hline $\mathrm{Ni}^{2+}$ & 0.26 & & 0.26 & 0.05 \\
\hline $\mathrm{Zn}^{2+}$ & 80.41 & $68-83$ & 5.7 & 0.2 \\
\hline $\mathrm{Pb}^{2+}$ & 1.47 & & & 0.01 \\
\hline $\mathrm{As}^{3+} / \mathrm{As}^{5+}$ & 0.06 & $1.37-2.73$ & & 0.05 \\
\hline $\mathrm{Cd}^{2+}$ & 0.36 & & 0.05 & 0.005 \\
\hline $\mathrm{Cr}^{6+}$ & 0.08 & & & 0.1 \\
\hline $\mathrm{Mn}^{2+}$ & 66.28 & $38-45$ & 9.7 & \\
\hline $\mathrm{Al}^{3+}$ & 63.43 & & & \\
\hline $\mathrm{Co}^{2+}$ & 0.38 & & 0.32 & 0.2 \\
\hline
\end{tabular}

*MAC-Maximum allowed concentration

Copper ions, as the main constituent of AMDs, appear in different $\mathrm{Cu}^{2+}$ concentrations, depending on the place of origin and the season. Various other ions are also present in significantly lower concentrations, with exception of ferric/ferrous ions, the concentration of which can vary in a wide range - from less than $1 \mathrm{ppm}$, up to several hundred ppm, as is shown in Table 1. In 
some cases, the concentration of iron ions can be almost twice higher, than the copper ones, as is the case with mine waters pumped out from the Bor Underground mine [4]. The concentration of $\mathrm{Fe}^{2+} / \mathrm{Fe}^{3+}$ depends mainly on the mine water $\mathrm{pH}$ value, but also on the composition of the place where it originates from. If mine waters are more acidic $(\mathrm{Ph}<3)$ iron will exist as $\mathrm{Fe}^{2+} / \mathrm{Fe}^{3+}$ ions. At the $\mathrm{pH} \geq 3$, ferric ions will spontaneously be precipitated as $\mathrm{Fe}(\mathrm{OH})_{3}$ interfering the established $\mathrm{Fe}^{2+} / \mathrm{Fe}^{3+}$ equilibrium and allowing further oxidation of ferrous ions with atmospheric $\mathrm{O}_{2}$ to ferric ones followed by their hydrolysis, according to the stoichiometry equations:

$4 \mathrm{Fe}^{2+}+\mathrm{O}_{2}+4 \mathrm{H}^{+} \rightarrow 4 \mathrm{Fe}^{3+}+2 \mathrm{H}_{2} \mathrm{O}$

$\mathrm{Fe}^{3+}+3 \mathrm{H}_{2} \mathrm{O} \leftrightarrows \mathrm{Fe}(\mathrm{OH})_{3}+3 \mathrm{H}^{+} \quad \mathrm{pH} \geq 3$

If the iron sulfide minerals from an ore body were altered in a greater extent through the geological period, one can expect higher content of iron oxides, as well as a higher percent of oxidized copper sulfide minerals, as it is the case with some copper mines, having an elevated percent of mixed oxide-sulfide ores. This particularly relates to shallower zones of ore bodies (oxide caps), which are more altered, but which will firstly be excavated at a mine opening. In general, wherever they emerge - from active or abandoned mines, as well as from mine dumps, AMDs have serious adverse effects on the surface- or groundwater, as well as to the soil. On the other hand, mine dumps and AMDs formed from them must particularly be considered as valuable secondary raw materials, which could be reprocessed, in order to extract residual metal, in a measure, that the applied technology allows. There are some approaches of implementing the new technologies, combining conventional with newly established processes, for this purpose [14, 15, and 21]. The problem is large and requires a concerted effort of different scientific disciplines, as well as a permanent collaboration with industry and governments. As a result of these joint efforts, novel technologies for AMDs treatment have emerged, or are still under research and development, with an aim of separating and concentrating some particular ionic constituents from, producing either commercial products or making environmentally friendly compounds. Adsorption could be a promising approach to the mine water purification, combined with other techniques, as is solvent extraction and electrowinning, for example [15].

\subsection{AMDs occurrences and their impact to the environment}

Currently, there are four active and abandoned copper mines, producing significant amounts of mine waters on various locations, shown as red spots on the map in Figure 1: Open pit Cerovo and Open pit Bor are closed mines, while Veliki Krivelj Copper Mine and Underground Mine Bor are the active ones, in which 7 AMD sites exist, within $15 \mathrm{~km}$ distance from Bor, Serbia. All the AMDs have similar chemical composition, but different metal potential, defined as:

$\mathrm{G}_{\mathrm{m}}=87.6 \cdot \mathrm{C}_{\mathrm{m}} \mathrm{Q}(=)$ t/year

Where: $G_{m}$ - a mass of metal in t/year; $C_{m}$ - concentration of metal ions in $A M D$ in $\mathrm{g} / \mathrm{m}^{3}, \mathrm{Q}$ - mine water flow rate in $m^{3} / h$.

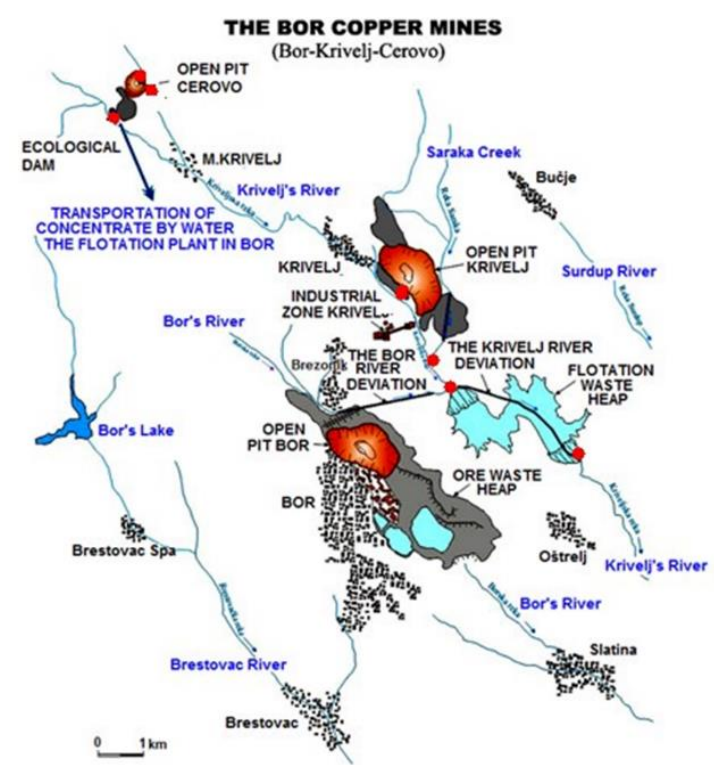

Figure 1 Local map of the copper mines in the Southeast Serbia: $\bullet$ AMD sites, according to [16]

\subsubsection{AMDs at the Cerovo Open Pit}

The map in Figure 1 shows that there are three red spots around the Cerovo Open Pit, which as such is between two rivers - the Krivelj - and the Cerova River. The biggest AMD, directed towards the Krivelj River, originates from a mine dump, which arose from out-ofbalance ore, and ore parties with an elevated oxidesulfide minerals content, as not suitable for the flotation 
concentration, were dumped at the edge of the Cerovo Open Pit, as shown in Figure 2. Shortly after the dump formation a pond with mine waters appeared at the dump foothill. To protect surface waters, downstream the pond, a dam was constructed, named internally the Ecology Dam. In order of keeping the mine water level constant, the pump-line was built up for the mine water transportation for feeding the cementation plant. Besides the Ecology Dam, there are two more springs of AMD on the opposite side of the Cerovo Mine, not far from each other, gravitating towards the Cerova River, here named as AMD 1 and AMD 2.

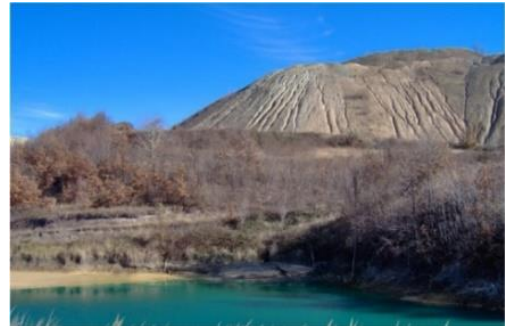

Figure 2 Photo of the mine dump and the mine water pond (the Ecology Dam) in its foothill nearby the closed copper mine Cerovo

Each of these three springs has different metal ions composition as is given in Table 2.

Table 2 Chemical composition of AMDs, originating from the considered copper mines

\begin{tabular}{lrrrrrrrrr}
\hline Metal ions mg/dm & Mn & $\mathrm{Cu}$ & $\mathrm{Fe}$ & $\mathrm{Ni}$ & $\mathrm{Co}$ & $\mathrm{Cd}$ & $\mathrm{Zn}$ & $\mathrm{Be}$ & $\mathrm{pH}$ \\
\hline Ecology Dam & 9.7 & 132.4 & 0.14 & 0.07 & 0.32 & 0.05 & 5.7 & 0.009 & $3.5-4$ \\
AMD 1 & 40.1 & 1050 & $<10$ & 0.5 & 2.1 & 0.2 & $>20$ & 0.003 & 3.5 \\
AMD 2 & 65.7 & 1550 & $<10$ & 1.1 & 5.6 & 0.4 & $>27$ & 0.0074 & 3.4 \\
Underground Mine & 21.4 & 87 & 316 & 0.76 & 0.54 & 0.11 & 7.7 & - & 2.8 \\
Saraka Creek & 13.9 & 6.15 & 38.6 & 0.27 & 1.3 & 0.02 & 1.67 & - & $>5$ \\
\hline
\end{tabular}

Unlike the Ecology Dam, AMDs 1 and 2, both have for one order of magnitude higher metal ions concentration. It implies, that these AMDs might originate from underground water streams passing through a part of the ore body containing higher percent of oxidized metal minerals. Very low iron ions concentration means there was significant alteration of sulphide minerals including pyrite before all, which were altered, due to chemical and biochemical transformation into hematite, goethite or limonite.
Because of this, natural $\mathrm{pH}$ of the ore is $\leq 4$ [17], indicating the presence of sulphuric acid, responsible for the leaching of other metal oxides and generation of the AMDs $[6,9]$

According to the map (Figure 1), there are several creeks, flowing into the Krivelj River. Some of them still have high water quality, while the Cerova River is worryingly damaged from two AMDs springing from the lateral slope of the open pit, close to the riverbank, as is illustrated in Figure 3.
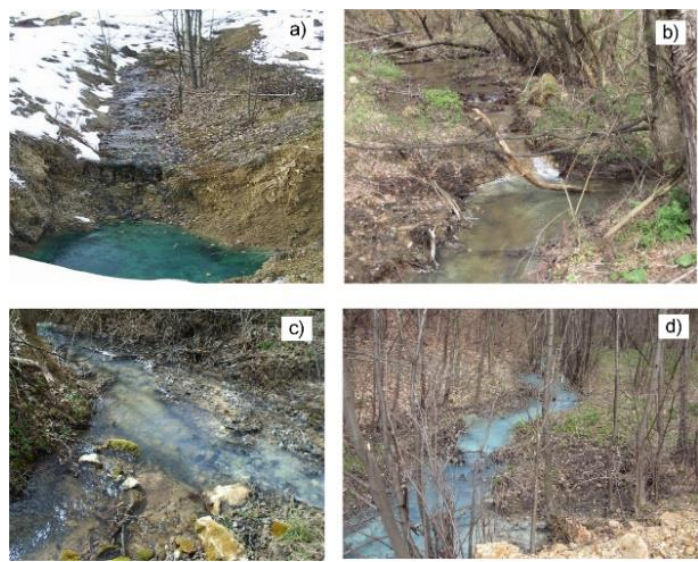

Figure 3 lllustration of the AMDs impact to surface waters: a - pond of the accumulated mine water; b - The Cerova River upstream from the AMD 1; c - A smaller creek confluence into the Cerova River; $d$ - The Cerova River polluted with mine water 
It is visible from the photos, how even the smallest AMD could have a catastrophic effect to the Cerova River downstream from the AMD 1 and 2 locations. Although, there is no overflow of the AMD, either a crack or a duct drains the accumulated mine water away from the AMD ponds into the river. Within the time, the river bed had got bluish-white colour, due to the copper ions hydrolysis, being transformed into hydroxides and precipitates covering the river bed. Precipitate transforms spontaneously into copper carbonate or hydro-carbonate due to $\mathrm{CO}_{2}$ naturally dissolved in water. Water quality of the Cerova River gets a bit improved by the inflow of a small creek (photo $c$ in Figure 3) but still polluted, affects the water quality of the Krivelj River, by flowing into it, as shown on the map in Figure 1.

\subsubsection{Mine waters from the Veliki Krivelj Mine}

There are two carriers of metal ions and sulphuric acid sourcing out from the Veliki Krivelj Mine. The one is mine water accumulated on the open pit bottom and pumped out to maintain normal work at the mine. The second source is the Saraka Creek flowing nearby the overburden dumpsite, formed from the mine wastes. Both mine water sources have significant flow-rates and an elevated content of suspended particles (See Figure $4 \mathrm{a})$, and a lower concentration of copper ions, varying from several ppm up to a few dozen ppm with an expressed tendency towards lower values, as well as with a $\mathrm{pH} \approx 4.5$ (See Table 2). The Saraka Creek flows into the Krivelj River, downstream from the Veliki Krivelj mine area, contributing further pollution of its water quality. Mine water from the open pit bottom is being pumped out and transported by a pipeline directly into the Krivelj River. Unlike the Saraka Creek, it contains a higher concentration of copper ions, on average $>50$ ppm, what increases significantly the copper losses with that water.

\subsubsection{Mine water from the Underground Mine Bor}

The largest and the oldest AMD originates from the Underground Mine. There are several independent springs inside the underground mine, which are collected at the deepest mine horizon, making an underground pond of so-called blue water which is characterized by a high concentration of copper ions, and approximately 2 to 4 times higher iron ions, and the $\mathrm{pH}<3$, as presented in Table $2[4,17]$. The blue water flow-rate is significant and amounts $>200 \mathrm{~m}^{3} / \mathrm{h}$. In an earlier period, to ensure normal underground mining, as well as for recovering copper, blue water was continuously pumped out into the cementation plant constructed specially for this purpose, producing a few hundred tons of cement copper for years. Recently, the cementation plant has been closed, so that the whole amount of copper contained in the blue water has been lost. At present time, the blue water is being pumped from the underground mine to be discharged partly into the Bor's River before its deviation (See Figure 1), while the rest is pumped into the flotation tailings dam. There are no reliable data about the partition - how much water flows into the flotation tailings dam, and how much into the river.

\subsubsection{State of the Krivelj River pollution and its impact to a wider environment}

Downstream of the Bor mine area, the Krivelj River is so polluted with acid, metal ions, and fine suspended particles, that it belongs to the fourth category of water, in which, apart from bacteria, there is no other living world $[10,17]$. Due to a long-lasting pollution, the Krivelj River banks and a narrow band of soil, are also overwhelmed with sedimented flotation silt, which is introduced into the Krivelj River, mainly by the Saraka Creek but also by the drainage water from the flotation tailings dam, making its waters turbid, what is visible from the photos in Figure 4, which illustrate details of the Saraka Creek (a) and the Krivelj River (b). The Krivelj River has been used for a long time as a synonym for extremely polluted water.

Flowing into the Timok River, the biggest river in Eastern Serbia, the Krivelj River pollutes its water and riverbank area, affecting even the Danube water quality at the confluence area, where a high concentration of copper, iron, and other heavy metals were found in the sediments [10]. Monitoring water quality of the Timok River along its flow from Zajecar to its confluence to the Danube through three months, by measuring the concentration of copper and iron ions, a concentration peak of these ions at the point, where the Krivelj River inflows into the Timok was found, which is illustrated in Figure 5.

Smaller peaks obtained in November occurred due to an increased water level of the Timok at that time. Sudden decrease of the ion concentration is attributed mainly to a dilution followed by hydrolysis of metal ions and formation of corresponding hydroxides and their spontaneous precipitation at those places, where the water flow was calmer. 


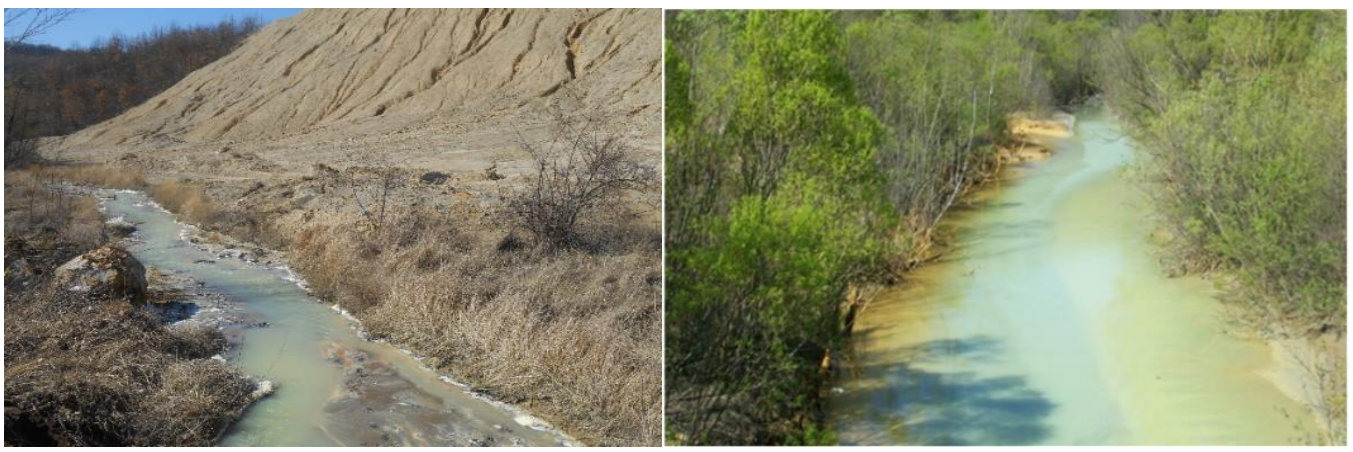

(a)

Figure 4 The Saraka Creek (a) and the Krivelj River (b)

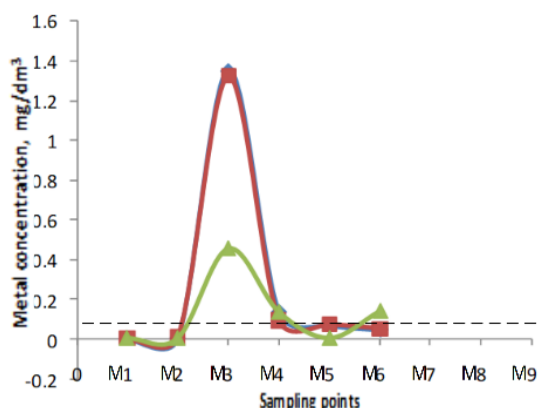

(a)

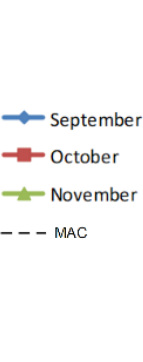

Figure 5 Distribution of $\mathrm{Cu}^{2+}(\mathrm{a})$ and $\mathrm{Fe}^{2+} / \mathrm{Fe}^{3+}(\mathrm{b})$ ions along the Timok, from Zajecar (M1) to its confluence

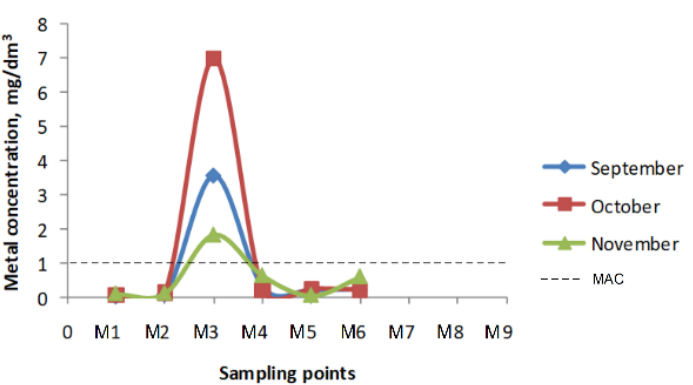

(b) into the Danube (M9); dashed line: maximum allowed concentration [10]

To summarize, the considered AMDs affect dramatically the Krivelj River water quality along its flow, as well as its river bank. Due to periodic flooding, the flotation silt has covered an undefined area of land by the river, making it completely unsuitable for any use. It means that the AMDs via the Krivelj River consequently affect the Timok water quality, its banks, and partly the surrounding land, in the same way as they have done to the Krivelj River. Since the Timok is partly a border river between Serbia and Bulgaria, the pollution, which the Krivelj River brings to the Timok, has several times caused diplomatic disputes between the two countries in the past.

\section{Balancing of the metal losses with the AMDs outflow}

\subsection{Copper losses with the mine water springs - current state}

Balancing mine water from different sources and the copper content in them is a thankless and heavy task, due to many variables influencing it, such as: AMD spot, flow-rate, concentration of ions, season of sampling, etc. Each of these variables significantly varies with the time of sampling. According to the map in Figure 1, three main sources of mine water were recognized: Cerovo Mine, Veliki Krivelj Mine, and Bor Underground Mine. To assess, as far as possible, reliable mean values on copper potential (See Eq. 7), water samples were taken quarterly from each the AMD source, within ten years (from 2006 to 2016) marked as a red spot on the map. Besides the water sampling, flow-rate was also measured, or estimated based on the working time of the installed pumps. Expectedly, obtained results of the samples analysis showed a great scattering, varying from each other even two-three times from year to year. Each source has shown a different mean annual copper potential, evaluated from the concentration of copper ions and water outflowing. The mean annual values of the flow-rate $Q$, concentration of copper ions $\mathrm{C}_{\mathrm{Cu}^{2+}}$, and the copper quantity $\mathrm{G}_{\mathrm{Cu}}$, for each of the AMD, are summarized and presented in Figure 6. 


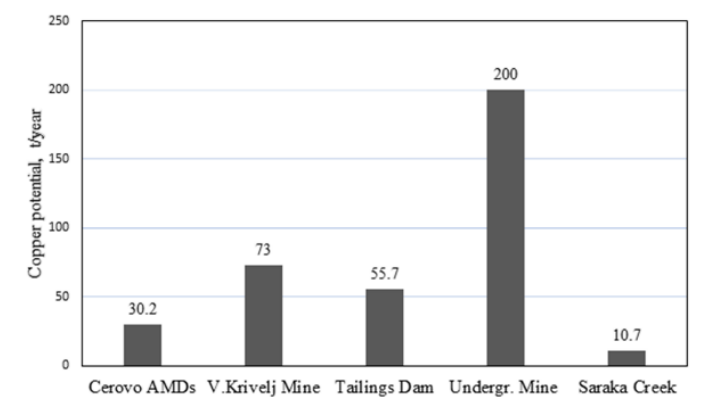

Figure 6 Copper losses from different sources generated in the copper mines (Based on $[4,18]$ )

As already mentioned, the AMD flow-rates vary in a wide range of values - from several thousand cubic meters up to more than 2 million $\mathrm{m}^{3} /$ year, depending on the season and place where it originates from. The copper potential, closely connected with the mine water flow-rate, also varies in a wide interval of values. According to Figure 6, an approximate total copper potential does not exceed 370 t/year. This amount of copper ions is sufficient to pollute any surface watercourse having the flow-rate lower than $120 \mathrm{~m}^{3} / \mathrm{s}$. The total copper potential has been lost through the Krivelj River so far, cutting down an overall metal extraction efficiency, which reflects directly to the company's income. Besides the copper losses, more than 500 t/year of $\mathrm{Fe}^{2+} / \mathrm{Fe}^{3+}$, as well as $\approx 30 \mathrm{t} /$ year of $\mathrm{Zn}^{2+}$ ions, as well as unknown amounts of $\mathrm{Mn}, \mathrm{Ni}, \mathrm{Co}, \mathrm{Y}$, and other transition metals were carried away with mine waters $[4,10,18]$. As $\mathrm{pH}$ varies very much from one AMD source to the other (See Table 2), the mass of $\mathrm{H}_{2} \mathrm{SO}_{4}$, roughly estimated, is amounted max $122 \mathrm{t} /$ year. Major acid amount, approximately 120 t/year, comes from both the Underground Mine and Cerovo mine AMDs. The Saraka Creek and the Veliki Krivelj Mine bring only about 2 to 3 t/year of $\mathrm{H}_{2} \mathrm{SO}_{4}$.

\subsection{A brief consideration of ways for mine waters treatment}

Decades of mine water discharge into the Krivelj River should not be allowed in the future, due to the growing pressure of domestic legislation, as well as the demands of the international community to reduce further pollution of the Timok water and then the Danube, as an important European waterway. With the strengthening of awareness about environmental protection and increased need for more rational water management, the pressures will be boosted, followed by relevant sanctions against the current copper producer.

Advanced mine water purification processes, in combination with conventional techniques, able to reduce the concentration of metal ions in mine water, can achieve the water quality to be discharged into the recipient $[1,8,16,19]$. Each of these technologies has its limitations in terms of applicability, the scope of purification, and economic viability.

According to Table 3, more than $50 \%$ of the total amount of copper comes from the underground mine blue water, making it the main source suitable for copper recovery from it. AMDs from the Cerovo Mine have been identified as the second copper source suitable for copper recovery. Water from these springs can easily be collected and transported to be mixed with blue water from the Underground Mine, and then all together treated. Mine water from the Open Pit Veliki Krivelj could also be considered for the copper removal, having an elevated copper potential. Water from the Saraka Creek, as well as streams sourcing from the tailings dam, should be treated separately, by employing some passive methods of processing $[1,19]$. At present, water from the flotation dam is partly reused in the flotation concentration plant, while a part flows, as drainage water, into the Krivelj River. Increasing the dam height will reduce the water leakage through it, achieving better management of that part of water. Water from the Saraka stream can be purified by a passive method for the deposition of suspended particles while reducing the concentration of metal ions and sulfuric acid by neutralization and precipitation. For this purpose, the construction of a reactive barrier with a pond seems to be a good method for its liberation from contended ions and suspended solids.

\section{Conclusions}

Acid mine drainages (AMDs) are a serious threat to the environment. Wherever an AMD appears, the mining company, as their owner, and the municipality around the copper mine must take care of them, minimizing their harmful impact on many parts of the ecosystem around the mine. Active or closed heavy metal mines, mining dumps, and other mining wastes are the sites where the AMDs comes from. Through this study, seven springs of mine waters were described i.e., their place of origin, their impact on the surrounding rivers, chemical composition, flow-rate, and other relevant features, 
based on which copper potential of each AMD was estimated.

This study has shown catastrophic effects of the AMDs from the three copper mines on the creeks and rivers in their neighborhood. All creeks and rivers are seriously deteriorated downstream of the mining area where they flow, due to continuous long-lasting extreme pollution by heavy metal ions and fine particles of clay and sand. It was found that the major volume of mine waters flows directly or indirectly (via its tributaries) into the Krivelj River, while a minor, not measurable volume is pumped to the flotation tailings dam, to be partly recycled and, as drainage water inflows into the Krivelj River. Its water belongs to the fourth category, with no living world in.

The flow-rate of each AMD varies very much, depending on the season and the place where it originates from, in a wide interval of values - from several thousand cubic meters per year, up to more than 2 million $\mathrm{m}^{3} /$ year. The copper content, and concentration, also vary in a wide interval of values. Approximately 360 to 370 tons of copper-, more than 500 tons of iron-, and around 30 tons of zinc ions, together with smaller amounts of other heavy metals, are being transported every year via the Krivelj River towards the Timok and the Danube.

Mine waters from the Underground Mine, as well as the AMDs from the Open-pit Cerovo, could be considered as recoverable, due to the copper concentration in these sources, their lower $\mathrm{pH}$, and the place of origin. That will contribute to lesser pollution of the Krivelj River by heavy metal ions and to cleaner copper production.

Long-term discharge of mine waters directly into the surrounding streams and rivers that were practiced in the RTB mines is economically unsustainable for the company and a crime against the environment.

\section{Acknowledgments}

The research presented in this paper was done with the financial support of the Ministry of Education, Science and Technological Development of the Republic of Serbia, within the funding of the scientific research work according to the contracts at the University of Belgrade, Technical Faculty in Bor with registration number 451-03-68/2020-14/ 200131, and the Mining and Metallurgy Institute Bor with registration number 451-03-68/2020-14/200052. Also, the authors want to thanks Mara Manzalovic professional English language professor from the University of Belgrade, Technical Faculty in Bor, for providing language assistance.

\section{References}

[1] Engineering Guidelines for the Passive Remediation of Acidic and/or Metalliferous Mine Drainage and Similar Wastewaters (2003). PIRAMID Consortium by HERO (Hydrogeochemical Engineering Research \& Outreach), University of Newcastle Upon Tyne, UK.

[2] Johnson, D.B., Hallberg, K.B. (2005) Acid mine drainage remediation option - a review. Science of the Total Environment 338, 3-14.

[3] Stuhlberger, C. (2010) Mining and environment in the Western Balkans. UNDP, UNEP, OSCE, NATO, UNECE and REC, Geneva, pp 108, http:// www.unep.at/documents_unep/Balkan_Feasibility_ Studies/Mining_Western_Balkans_2001_01_11.pdf

[4] Stanković, V., Žikić, M., Bogdanović, G., Milanović, Z., Marjanović, T. (2012) Mine waters from RTB Bor - Potential for copper production or surface waters polluter. In: 3rd Symposium "Mining". Zlatibor, Serbia, Proceedings, 402-405.

[5] Stuhlberger, C., Peck, A.P., Tremblay, A.G., Dave, N. (2007) Innovative Techniques and Technologies for Contaminated Mine Waters Assessment, Management and Remediation. Technical Workshop Report. Geneva: Environment and Security Initiative.

[6] Gorgievski, M., Božić, D., Stanković, V., Bogdanović, G. (2009) Copper electrowinning from acid mine drainage: A case study from the closed mine "Cerovo". Journal of Hazardous Materials 170, 716-721.

[7] Kalin, M., Fyson, A., Wheeler, W.N. (2006) The chemistry of conventional and alternative treatment systems for the neutralization of acid mine drainage. Science of the Total Environment 366 (2-3), 395-408.

[8] Habashi, F. (1999) A Textbook of Hydrometallurgy 2nd edition. Laval University, Quebec City, Canada.

[9] Simate, G.S., Ndlovu, S. (2014) Acid mine drainage: Challenges and opportunities. Journal of Environmental Chemical Engineering 2, 1785-1803.

[10] Group of authors. (2010) The causes of water contamination and analysis of Timok basin from the City of Zajecar to its confluence with the Danube. 
Project Report. Institute of Chemical Engineering and Metallurgy (IHTM), Belgrade, Serbia.

[11] Stanković, V., llić, I., Živković, D., Antonijević, M., Bogdanović, G., Nikolić, B., Nikolić, V., Miljković, D. (2011) Loading of the Timok river with heavy metal ions. In: 9th ECO-conference on environmental protection of urban and suburban settlements. Novi Sad, Serbia, Proceedings, 167-173.

[12] Asta, M.P., Ayora, C., Acero, P., Cama, J. (2010) Field rates for natural attenuation of arsenic in Tinto SantaRosa acid mine drainage (SW Spain). Journal of Hazardous Materials 177, 1102-1111G.

[13] Chen, T., Yana, B., Lei, C., Xiao, X. (2014) Pollution control and metal resource recovery for acid mine drainage. Hydrometallurgy 147-148, 112-119.

[14] Savov, G., Angelov, T., Tsekov, Al., Grigorova, I., Nishkov, I. (2012) Combination of IX and SX vs. SX, a Technical-economical comparison. In: XXVI International Mineral Processing Congress (IMPC 2012). New Delhi, India, Proceedings, 1-8.

[15] Stanković, V. (2007) Metal Removal from Effluents by the Electrowinning and a New Design Concept in Wastewaters Purification Technology. Chemical and Biochemical Engineering Quarterly 21(1), 33-45.

[16] Stanković, V. (2020) „AMDs from copper mines - A dramatic threat to local water flows or a valuable source for copper production". Plenary lecture In: 28th International Conference Ecological Truth and Environmental Research. Kladovo, Serbia, Proceedings, 3 .
[17] Bogdanović, G., Stanković, V., Trumić, M., Antić, D. (2016) Leaching of low-grade copper ores: A case study for 'Kraku Bugaresku-Cementacija' deposits (Eastern Serbia). Journal of Mining and Metallurgy A Mining 52(1), 45-56.

[18] Božić, D., Marković, R., Masuda, N., Gardić, V., Stevanović, Z., Obradović, Lj., Bessho, M. (2017) Metal losses caused by acid mine drainage. In: 49th International October Conference on Mining and Metallurgy, Bor Lake, Serbia, Proceedings, 354-357.

[19] Younger, P.L. (2002) Coalfield closure and the water environment in Europe. Transactions of the Institutions of Mining and Metallurgy: Section A 111(3), 201-209.

[20] Kefeni, K.K., Msagati, T.A.M., Mamb, B.B. (2017) Acid mine drainage: Prevention, treatment options, and resource recovery: A review. Journal of Cleaner Production 151, 475-493.

[21] Marković, R., Bessho, M., Masuda, N., Stevanović, Z., Božić, D., Apostolovski Trujić, T., Gardić, V. (2020) New Approach of Metals Removal from Acid Mine Drainage. Applied Sciences 10 (17), 5925.

[22] Regulation on emission limit values of polluting substances in surface and groundwaters and deadlines for their achievement ("Official Gazette of the RS", No. 50/12).

[23] Regulation on limit values of priority substances and priority hazardous substances that pollute surface waters and deadlines for their achievement ("Official Gazette of the RS", No. 24/14). 


\title{
KISELE RUDNIČKE VODE IZ RUDNIKA BAKRA U JUGOISTOČNOJ SRBIJI - LOKALNI PROBLEM SA UTICAJEM NA MEĐUNARODNOM NIVOU
}

\author{
V. Stanković1" D. Božić2 ${ }^{1}$ M. Gorgievski', G. Bogdanović1 ${ }^{1}$ M. Žikić1 \\ 1 University in Belgrade, Technical Faculty, Bor, Serbia \\ ${ }^{2}$ Mining and Metallurgy Institute Bor, Bor, Serbia \\ Primljen: 29. januar 2021.; Prihvaćen: 20. April 2021.
}

\begin{abstract}
Izvod
U ovom radu posebna pažnja je posvećena kiselim rudničkim vodama (AMD) koje potiču iz rudnika bakra, a koje sadrže različite jone teških metala i određenu količinu sumporne kiseline. Istraživanje je sprovedeno na prostoru koji obuhvata rudnike u sklopu RTB Bor (danas Srbija Zijin Bor Copper). Utvrđeno je postojanje kiselih rudničkih voda, njihov sastav, potencijal za ekstrakciju metala i uticaj na lokalne površinske vode. Najveća količina rudničkih voda se uliva u Kriveljsku reku što izuzetno narušava njen kvalitet. Istraživanje je takođe obuhvatilo i praćenje kvaliteta vode reke Timok duž njenog toka od mesta gde se Kriveljska reka uliva u nju do ušća u Dunav. Procenom gubitka metala utvrđeno je da se svake godine izgubi oko 360 tona bakra, više od 500 tona gvožđa i 30 tona cinka u rudničkim vodama koji se preko Kriveljske reke transportuju do Timoka, a zatim do Dunava.
\end{abstract}

Ključne reči: Joni teških metala; Rudarski otpad; Rudnička voda; Kisele rudničke vode (AMD); Zagađenje vode. 